\title{
SPECTRUM OF LESIONS IN NEPHRECTOMY SPECIMENS IN TERTIARY CARE HOSPITAL
}

Shaila1 ${ }^{1}$ Nityananda B. S2, Tamil Arasi ${ }^{3}$

\section{HOW TO CITE THIS ARTICLE:}

Shaila, Nityananda B. S, Tamil Arasi. "Spectrum of Lesions in Nephrectomy Specimens in Tertiary Care Hospital". Journal of Evolution of Medical and Dental Sciences 2015; Vol. 4, Issue 73, September 10; Page: 12714-12726, DOI: $10.14260 /$ jemds/2015/1832

ABSTRACT: CONTEXT: Nephrectomy is a standard surgical procedure in urological practice performed in end stage/nonfunctioning kidney or in suspected malignant neoplasm. AIM: A retrospective \& prospective review of histopathological lesions including rare lesions encountered in different age group \& genders amongst nephrectomy specimens received in department of pathology. METHODOLOGY: Study included total 106 nephrectomy cases over a period of 5 years, (March 2010 to February 2015.) RESULT: In this study the most common lesions were inflammatory (77.36\%), \{vast majority being chronic nonspecific pyelonephritis $(60.38 \%)$, \} followed by malignant neoplasm (18.8\%) \& benign neoplasms (3.77\%). Most common age group was 4th to 5th decade for inflammatory lesions, and 6th to 7th decade for malignant lesions. Clear cell sarcoma kidney in a child \& transitional carcinoma in an adult were the rare lesions encountered. CONCLUSION: Common lesion encountered was chronic nonspecific pyelonephritis, followed by renal cell carcinoma. Clear cell sarcoma kidney in a child, \& transitional carcinoma in an adult were the rare lesions in the study.

KEYWORDS: Nephrectomy, Renal cell carcinoma, Clear cell sarcoma, Mesoblastic nephroma.

INTRODUCTION: Kidneys are vital organs of the body with multiple functions. They are essential for not only excretory function but also to maintain water and salt metabolism along with acid base balance. In addition they maintain the blood pressure through renin-angiotensin mechanism and produce erythropoietin required for hematopoiesis.

Nephrectomy is the standard surgical procedure performed in the context of end stage renal disease and in the case of suspected malignant renal disease. The most common indication for nephrectomy is loin pain, hematuria, mass in the abdomen and a radiological evidence of minimal excretory activity of the kidney through procedures of IVP and ultrasound. ${ }^{1}$ Simple nephrectomy is indicated in patients with irreversible kidney damage and also indicated to treat Reno vascular hypertension while radical nephrectomy is the treatment of choice for renal cell carcinoma (RCC). ${ }^{2}$

Among the non-neoplastic indications in nephrectomies, non-functioning kidney in obstructive nephropathies and chronic pyelonephritis are the most common. ${ }^{3}$ The management of severely diseased tuberculous kidney is indisputable and mandatory. ${ }^{4}$ Among neoplastic lesions in kidney renal cell carcinoma accounts for 80-85 percent of malignant kidney tumors. ${ }^{5}$ Nephroblastoma (Wilms tumor) is the most common malignant pediatric renal tumor usually seen at age 2-5 years. Multicystic nephroma is a rare benign cystic lesion of kidney \& it is grouped under mixed epithelial \& stromal tumor in WHO classification of renal tumors. ${ }^{6}$ Clear cell sarcoma kidney \& congenital mesoblastic nephroma (CMN) are rare in children.

AIMS AND OBJECTIVES: The objective of the present study is assess the spectrum and frequency of the different pathological lesions: 


\section{ORIGINAL ARTICLE}

- To study the histopathological features of lesions in the nephrectomy specimen.

- To analyze the neoplastic lesion of kidney according to age, gender, site and histopathology.

- To evaluate the rare case of renal neoplasm.

METHODOLOGY: The present study was conducted in the Department of Pathology in collaboration with the Department of Urology and Pediatric surgery of this institute, and included all nephrectomy specimens received in this department over a period of 5 years from March 2010 to February 2015. The study was included retrospective 3 years and prospective 2 years. A total of 106 cases were included in the study. For retrospective cases, paraffin blocks and slides along with case records were retrieved and studied. All the nephrectomy specimens were fixed in $10 \%$ formalin and thorough gross examination was done as per standard guidelines.

Grossing of formalin fixed specimen and processing of tissue was done according to standard protocol. H \& E stained sections were studied. Special stains \& immunohistochemistry was also done where ever needed. Patient particulars were recorded in detail including investigations like USG \& CT scan findings. The cases were reviewed with respect to age, sex, right or left, pathological diagnosis, clinical presentation, laboratory investigations.

RESULT: The present study included all 106 nephrectomy cases received during the study period. Among them female patients were 61 cases (57.55\%), male patients were 45 cases $(42.45 \%)$ (Table1). Youngest age was 11 days (CMN), and oldest age was 72 years (TCC).

Highest percentage of patients undergoing nephrectomy belonged to 41-50 years age group with $27.36 \%$ (29cases). Lowest percentage of patients belonged to $<10$ years age group with $6.6 \%$ ( 7 cases) (table-1).

Among 106 nephrectomies received during the study period 82 cases (77.36\%) were non neoplastic, 4 cases (3.77\%) were benign neoplastic, 20 cases (18.87\%), chronic pyelonephritis (CPN) was the commonest disease encountered - 64 cases $(60.38 \%)$ were malignant neoplastic cases.

\begin{tabular}{|c|c|c|c|c|c|c|c|c|c|}
\hline Age(years) & $<\mathbf{1 0}$ & $\mathbf{1 1 - 2 0}$ & $\mathbf{2 1 - 3 0}$ & $\mathbf{3 1 - 4 0}$ & $\mathbf{4 1 - 5 0}$ & $\mathbf{5 1 - 6 0}$ & $\mathbf{> 6 1}$ & Total & $\mathbf{\%}$ \\
\hline Female & 4 & 6 & 10 & 11 & 16 & 7 & 7 & 61 & 57.55 \\
\hline Male & 3 & 6 & 6 & 8 & 13 & 8 & 1 & 45 & 42.45 \\
\hline Total & $\mathbf{7}$ & $\mathbf{1 2}$ & $\mathbf{1 6}$ & $\mathbf{1 9}$ & $\mathbf{2 9}$ & $\mathbf{1 5}$ & $\mathbf{8}$ & $\mathbf{1 0 6}$ & 100 \\
\hline $\mathbf{9}$ & 6.60 & 11.32 & 15.09 & 17.92 & 27.36 & 14.15 & 7.55 & 100 & \\
\hline & Table 1: Age \& sex wise distribution of renal lesions \\
\hline
\end{tabular}




\section{ORIGINAL ARTICLE}

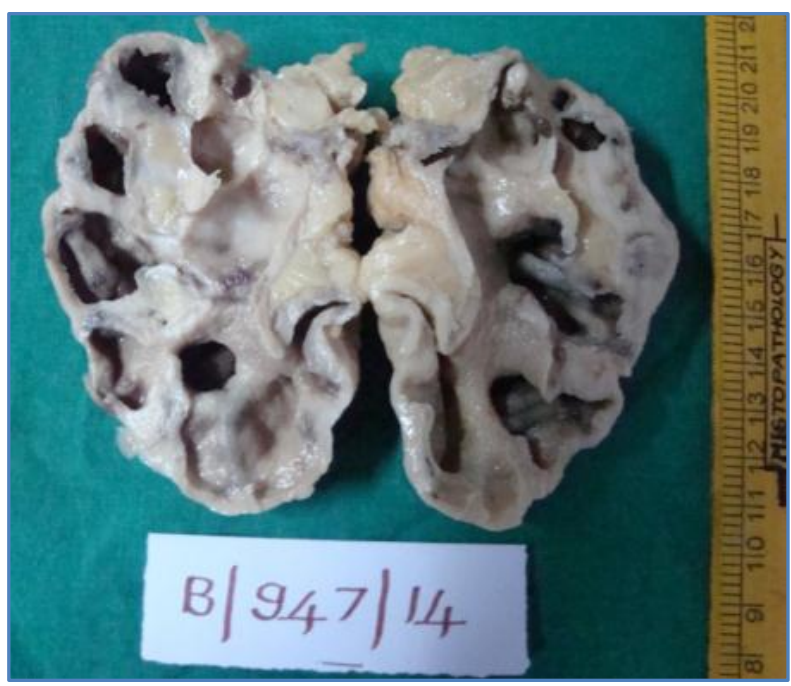

Fig. 1: Chronic pyelonephritis with

hydronephrosis \& renal calculi

Among 82 non-neoplastic diseases encountered 64(60.38\%) were nonspecific pyelonephritis cases, 12(11.32\%) were tuberculous pyelonephritis (AFB +VE) cases, 2 cases (1.89\%) were xanthogranulomatous pyelonephritis, 2 (1.89\%) were hypo plastic kidneys. $1(0.94 \%)$ case each was of traumatic kidney and hydatid cyst of kidney.

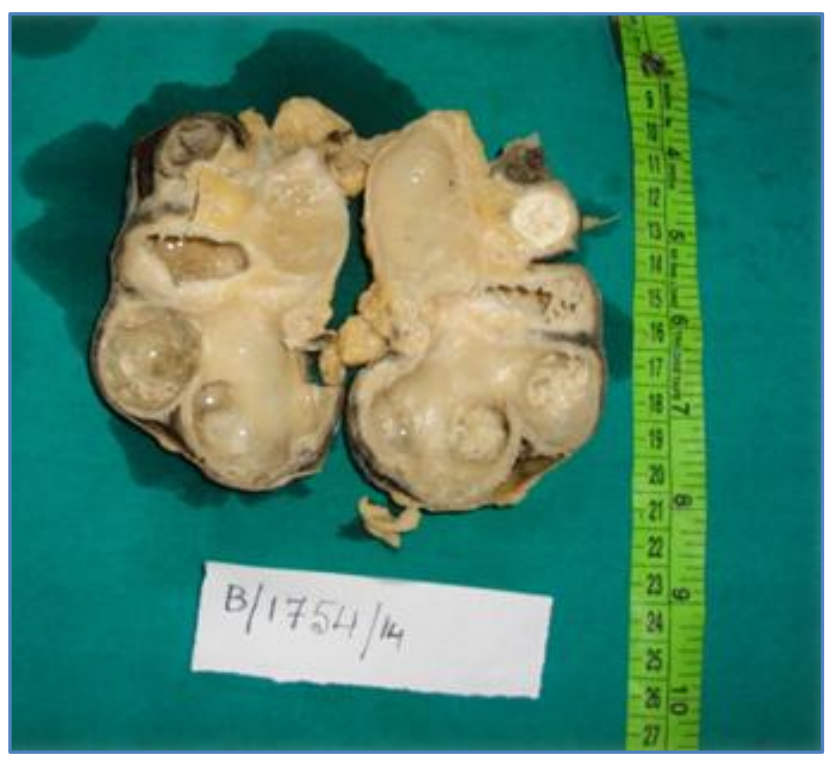

Fig. 2: Tuberculous pyelonephritis

Among total nephrectomies, 4(3.77\%) benign neoplastic lesions were encountered, among which $2(1.84 \%)$ cases were oncocytoma, 1(0.94\%) each were of multicystic nephroma \& adult polycystic kidney disease. Among 20(18.87\%) cases of malignant neoplastic lesions, $12(11.32 \%)$ were renal cell carcinoma, 5(4.72\%) were Wilm's tumor, 1(0.94\%) case each of clear cell sarcoma kidney, congenital mesoblastic nephroma \& transitional cell carcinoma. 


\section{ORIGINAL ARTICLE}

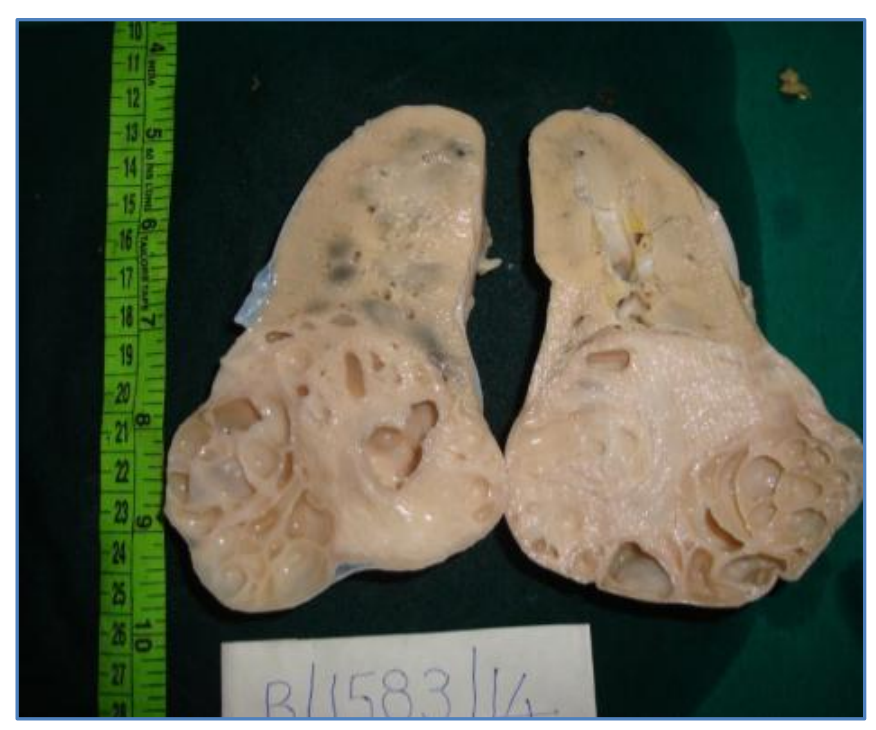

Fig. 3a: Multicystic Nephroma

Most common clinical presentation of patients who underwent nephrectomy was flank pain seen in 80 cases, which is followed by fever (55 cases), hematuria (30 cases) and least common symptom was epigastric pain ( 2 cases). Pediatric neoplastic cases presented with fullness \& mass in the abdomen.

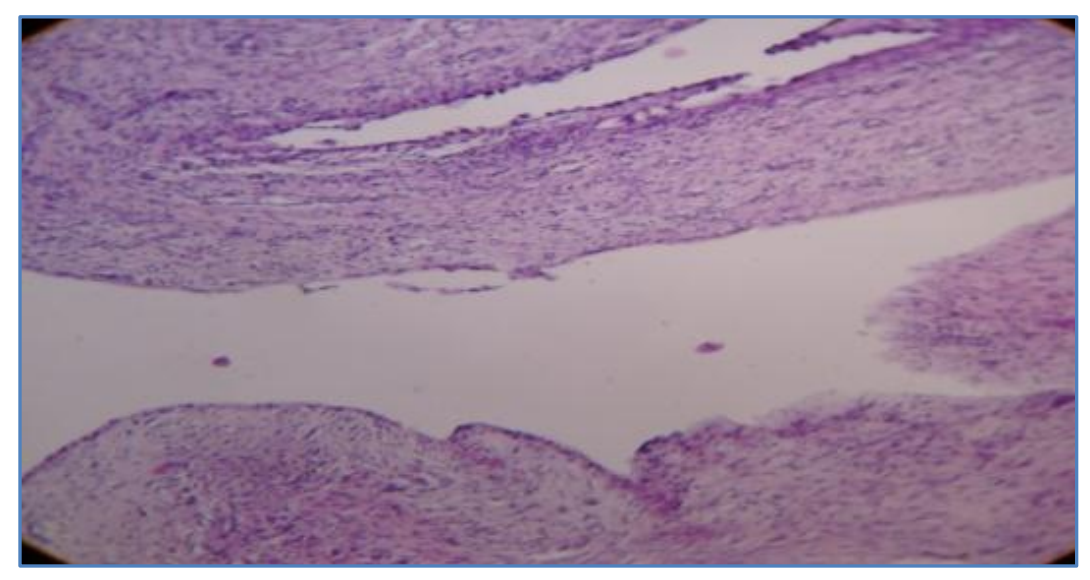

Fig. 3b: Multicystic Nephroma (x40)

Out of 106 nephrectomies 62 cases were left sided kidneys and 44 cases were right sided one. Out of 106 gross specimens of nephrectomies, 64 were nonspecific pyelonephritis cases, 48 were associated with calculus pyelonephritis which were showing hydronephrosis with dilated pelvis calycyeal system and thinned out cortex. Other inflammatory lesions encountered were tuberculous pyelonephritis $12(11.32 \%)$ cases and two cases of xanthogranulomatous pyelonephritis (1.89\%), 1 case of hydatid cyst $(0.94 \%)$.

The non-inflammatory, non-neoplastic indications or nephrectomy were $2(1.84 \%)$ cases of hypo plastic kidney, \& $1(0.94 \%)$ case of traumatic rupture of kidney. 


\section{ORIGINAL ARTICLE}

\begin{tabular}{|c|c|c|c|c|c|c|c|c|c|}
\hline $\begin{array}{l}\text { Sl. } \\
\text { No. }\end{array}$ & Lesions & $<10$ yrs. & $11-20$ & 21-30 & $31-40$ & 41-50 & $51-60$ & $>60$ yrs. & Total \\
\hline 1 & $\begin{array}{c}\text { Chronic } \\
\text { pyelonephritis }\end{array}$ & 0 & 7 & 9 & 15 & 22 & 10 & 1 & 64 \\
\hline 2 & $\begin{array}{c}\text { Tuberculous } \\
\text { pyelonephritis }\end{array}$ & 0 & 2 & 4 & 2 & 4 & 0 & 0 & 12 \\
\hline 3 & $\begin{array}{c}\text { Xanthogranulomatous } \\
\text { pyelonephritis }\end{array}$ & 0 & 0 & 2 & 0 & 0 & 0 & 0 & 02 \\
\hline 4 & Hydatid cyst & 0 & 1 & 0 & 0 & 0 & 0 & 0 & 01 \\
\hline 5 & Hypo plastic kidney & 1 & 1 & 0 & 0 & 0 & 0 & 0 & 02 \\
\hline 6 & $\begin{array}{c}\text { Traumatic } \\
\text { rupture of kidney }\end{array}$ & 0 & 0 & 1 & 0 & 0 & 0 & 0 & 01 \\
\hline 7 & $\begin{array}{l}\text { Polycystic kidney } \\
\text { disease(adult) }\end{array}$ & 0 & 0 & 0 & 0 & 0 & 1 & 0 & 01 \\
\hline 8 & Multisystem nephroma & 0 & 0 & 0 & 1 & 0 & 0 & 0 & 01 \\
\hline 9 & Oncocytoma & 0 & 0 & 0 & 0 & 2 & 0 & 0 & 02 \\
\hline 10 & Renal cell carcinoma & 0 & 0 & 0 & 1 & 1 & 4 & 6 & 12 \\
\hline 11 & Wilm's tumor & 5 & 0 & 0 & 0 & 0 & 0 & 0 & 05 \\
\hline 12 & $\begin{array}{c}\text { Congenital mesoblastic } \\
\text { nephroma }\end{array}$ & 1 & 0 & 0 & 0 & 0 & 0 & 0 & 01 \\
\hline 13 & Clear cell sarcoma & 0 & 1 & 0 & 0 & 0 & 0 & 0 & 01 \\
\hline 14 & $\begin{array}{c}\text { Transitional } \\
\text { cell carcinoma }\end{array}$ & 0 & 0 & 0 & 0 & 0 & 0 & 1 & 01 \\
\hline & Total & 7 & 12 & 16 & 19 & 29 & 15 & 8 & 106 \\
\hline
\end{tabular}

Under neoplastic conditions we encountered, Renal cell carcinoma was the most common, comprising of $11.32 \%$ (12 cases) of all nephrectomies followed by Wilm's tumor - 5 cases(4.72\%), \& 1 case each(0.94\%)of clear cell sarcoma, congenital meroblastic nephroma and transitional cell carcinoma.

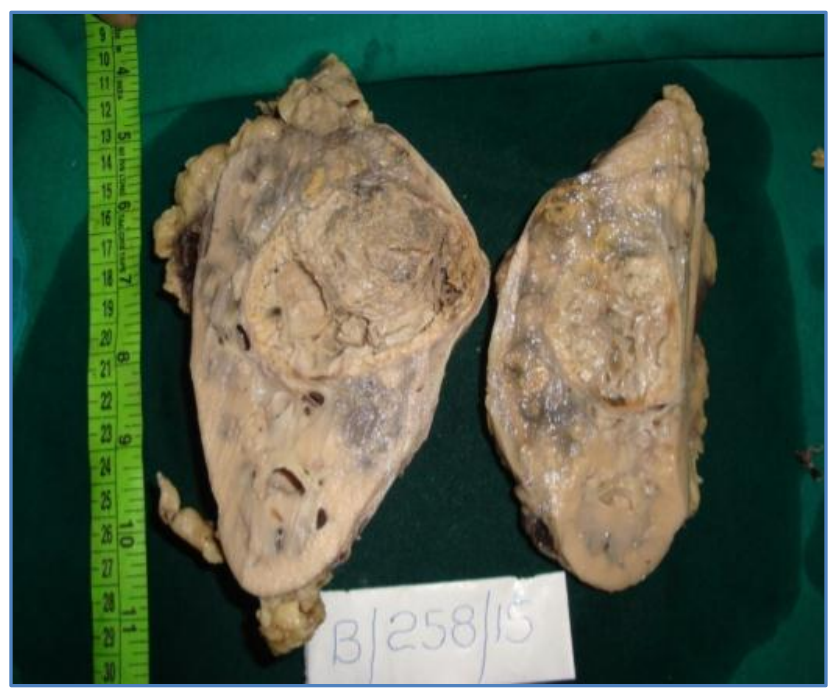

Fig. 4: Renal cell carcinoma (Papillary type)

The histological types of renal cell carcinomas were, 7 cases of (58.3\%) clear. 


\section{ORIGINAL ARTICLE}

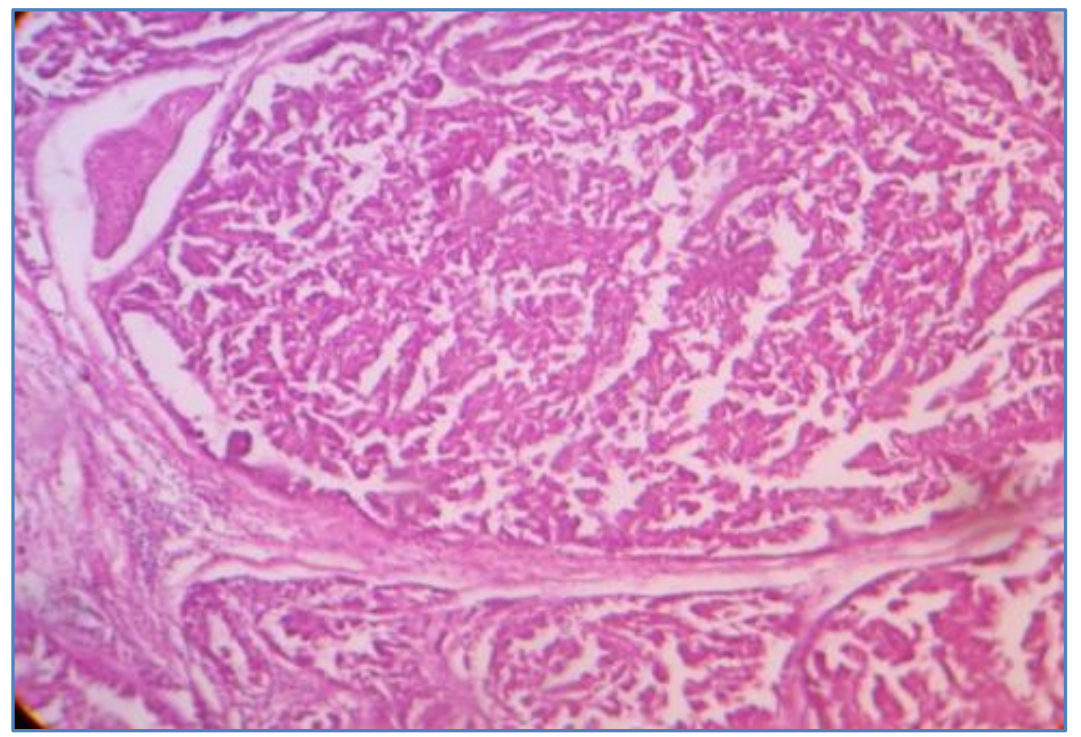

Fig. 5: Papillary variant of renal cell carcinoma (40X)

Cell type, 4 cases $(33.33 \%)$ were papillary variants \& 1 case $(8.3 \%)$ was chromophobe variant. Fuhrman nuclear grading in all the cases of renal cell carcinomas shows grade 2 to 3 nuclear feature.

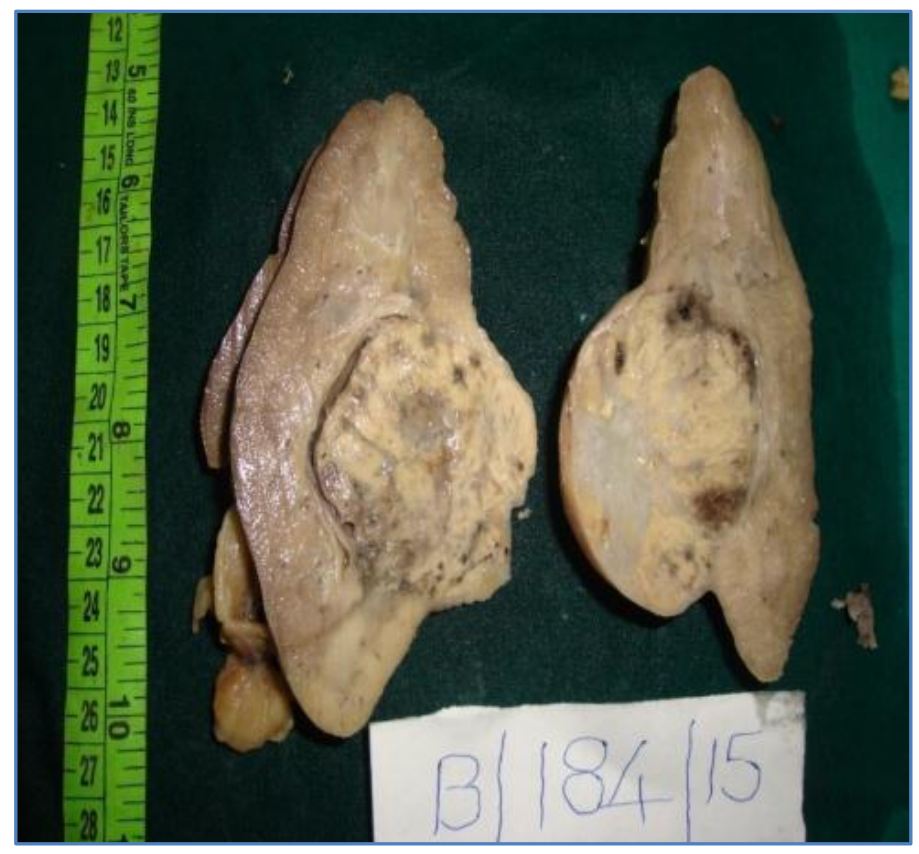

Fig. 6: Renal cell carcinomac(Clear cell varient)

The present study included 5 cases of Wilm's tumor in the age group of 2 to 6 years. Microscopically 3 cases had triphasic (blastemal, epithelial \&mesenchymal) lineage, and 2 cases had biphasic lineage. None of them had unfavorable histology. All the malignant lesions were of stage 1. 


\section{ORIGINAL ARTICLE}

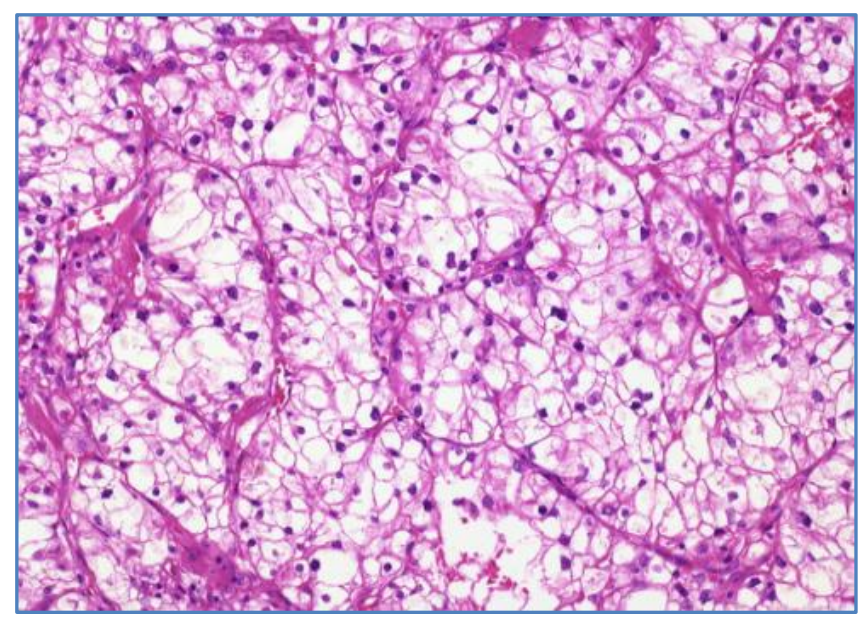

Fig. 7: Clear cell variant of RCC (40X)

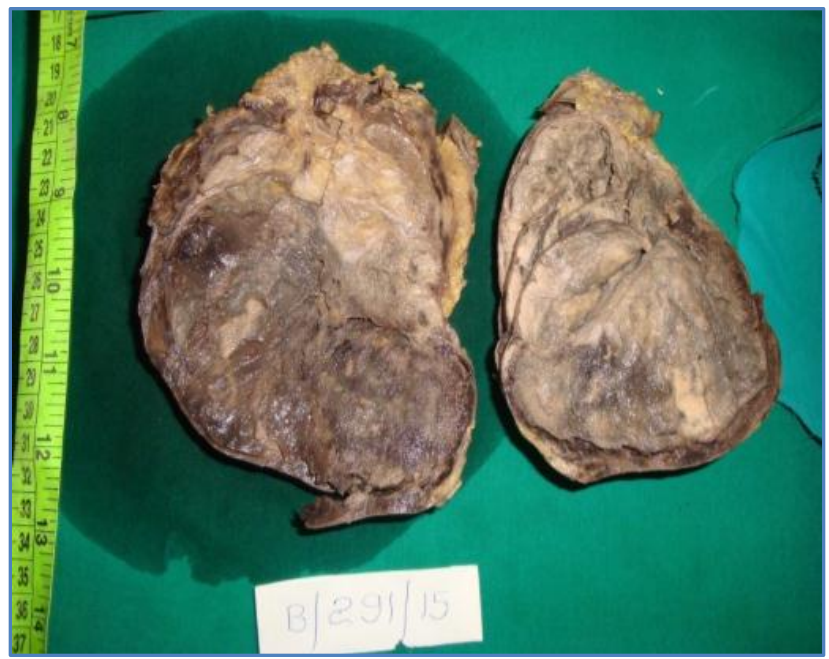

\section{Fig. 8: Renal cell carcinoma (Chromophobe variant)}

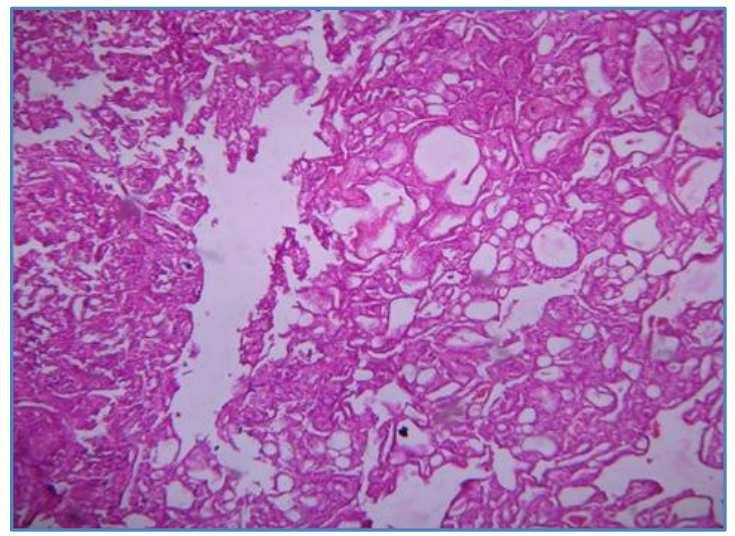

Fig. 9: Chromophobe variant of RCC (40x) 


\section{ORIGINAL ARTICLE}

One $(0.94 \%)$ case of clear cell sarcoma kidney in a 12 year old female child is included in our study. Gross examination revealed, right nephrectomy specimen measuring $8.5 \times 5 \times 4 \mathrm{~cm}$, with circumscribed tumor mass measuring $7 \times 4 \mathrm{~cm}$, with grey white solid cut surface with areas of necrosis $\&$ hemorrhage. (Figure.11). Tumor was invading the renal capsule... Microscopic picture showed highly cellular tumor consisting of proliferating monotonous unidentified malignant cells with moderately clear to faint eosinophilic cytoplasm, nucleus was anisokaryotic with inconspicuous nucleoli. \&2-3 mitosis/hpf.

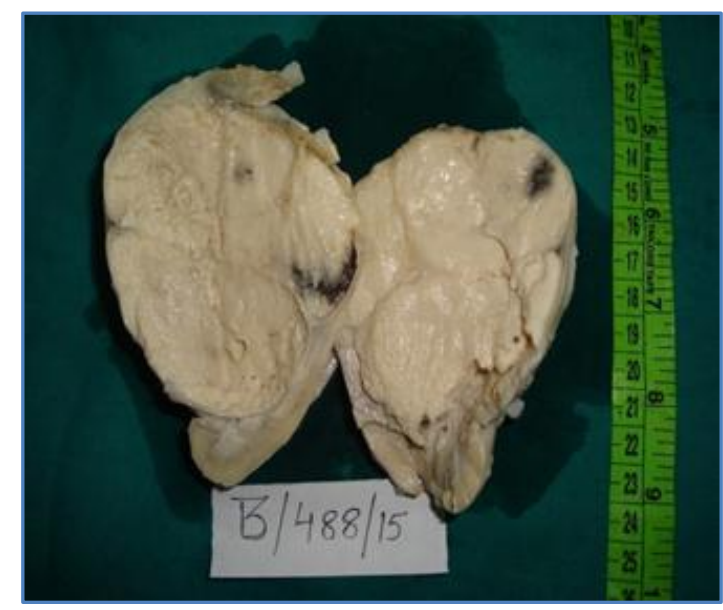

Fig. 10: Wilms tumor

And intervening delicate vascular stroma. (Figure12.).Immunohistochemistry revealed focal vimentine positive. \& cytokeratin, NSE negative.

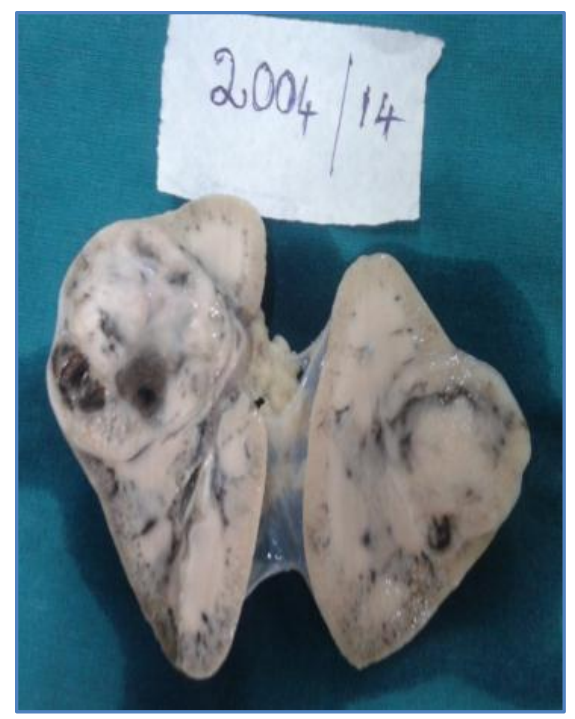

\section{Fig. 11: Clear cell sarcoma kidney}

Another rare case in our study was congenital mesoblastic nephroma operated in 11day old infant, with history of maternal hydramnios, premature birth, abdominal mass. The nephrectomy specimen revealed a grey brown circumscribed fleshy mass with hemorrhage \&cystic degeneration. (Figure14A.)Microscopically, cellular varient with sheet like proliferation of plump atypical spindle cells with moderate cytoplasm \& vesicular nucleus, 5-6 mitosis/hpf (Figure, 14B) 


\section{ORIGINAL ARTICLE}

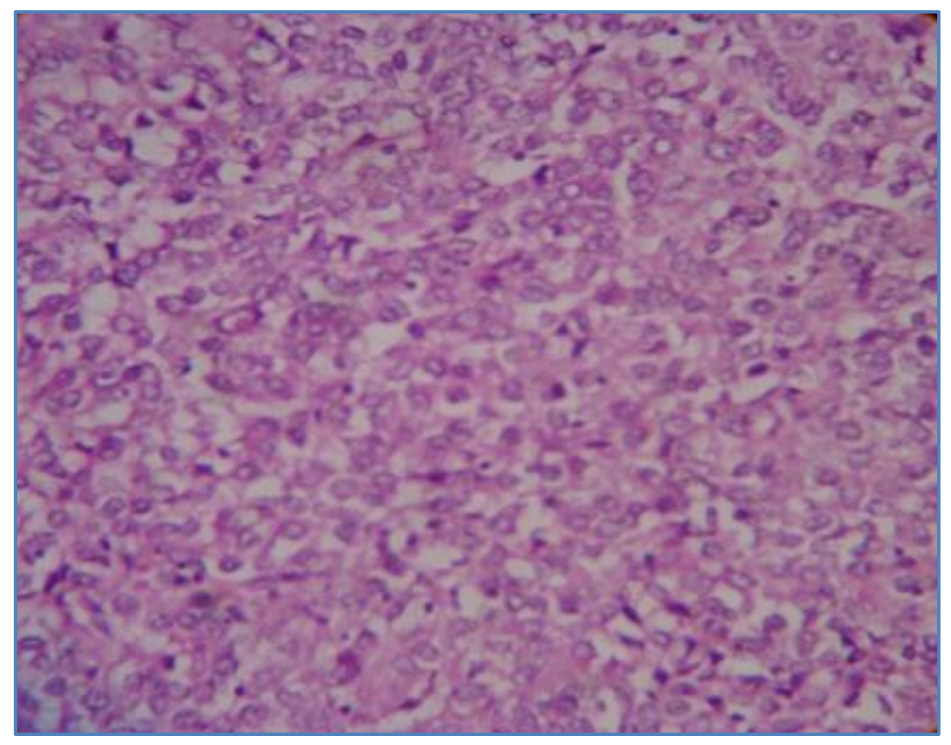

Fig. 12: Clear cell sarcoma (40x)

The present study included a case of high grade transitional cell carcinoma of renal pelvis in a72 year old male patient. (Fig-13)

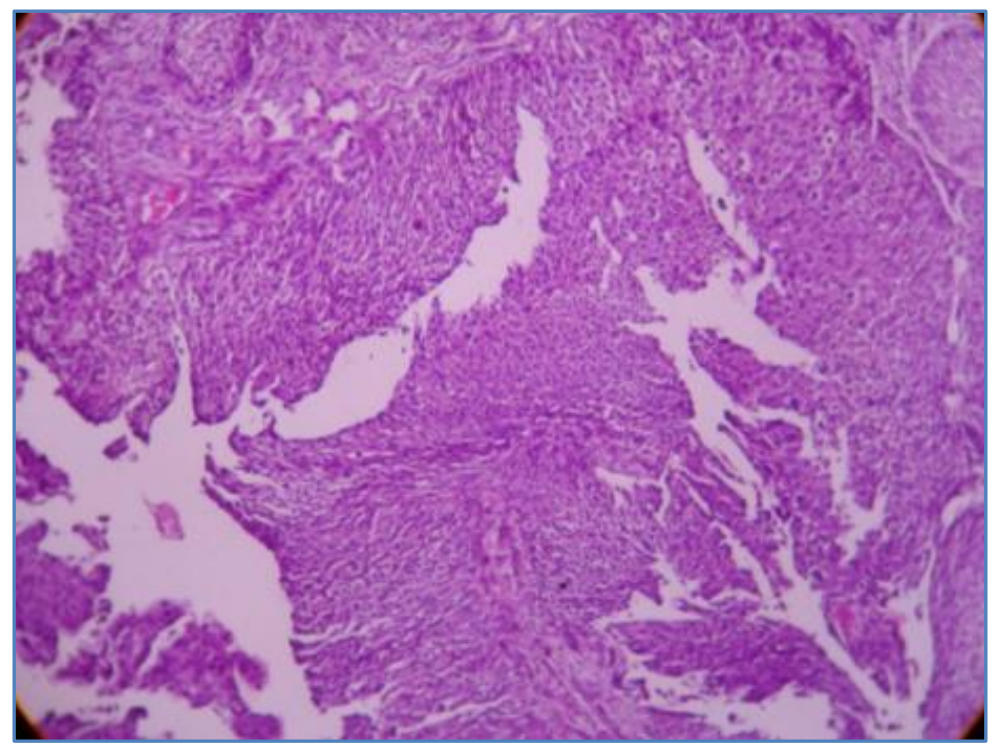

Fig. 13: Transitional cell carcinoma of renal pelvis

Among the benign neoplastic lesions, multicystic nephroma is unusual one. A 33 year old woman, presented with mild persistent left flank pain. Ultrasound scanning revealed a multicystic mass having multiple thick septae. The nephrectomy specimen showed a lobulated outer surface. While the cut surface revealed numerous cysts in the lower half portion of kidney. Cysts were filled with serous fluid. (Figure-3a) Microscopic examination showed multiple cysts lined by flattened to low cuboidal epithelium. (Figure-4b.) 


\section{ORIGINAL ARTICLE}

Fig. 14: Mesoblastic nephroma, (A) Gross, (B) Microscopy (40x).

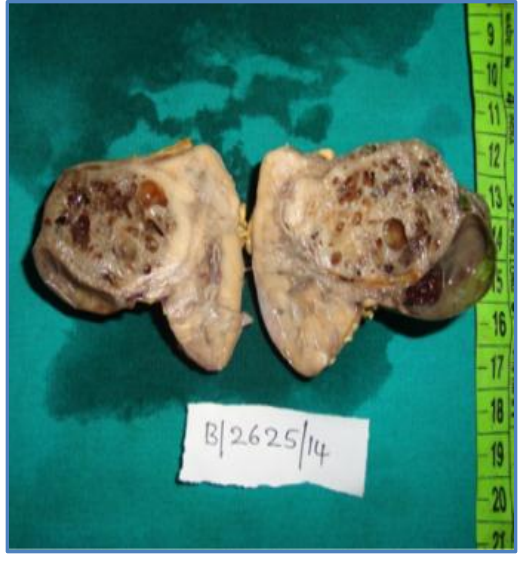

Fig. 14 A

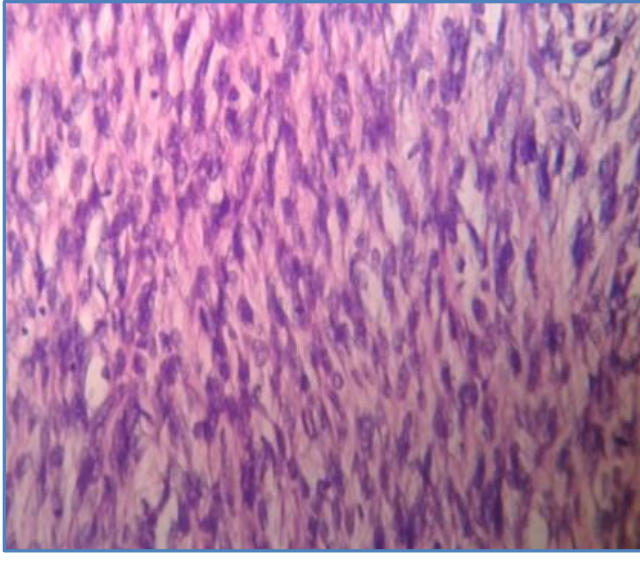

Fig. 14 B

DISCUSSION: In our study 106 nephrectomy cases were analyzed. There were 86 cases (81.13\%) were benign lesions, 20 cases (18.87\%) were malignant lesions. There was a vast majority of benign lesion in our study. Similar study was observed by Aifa Aiman et al.,7 \& others.8,9 (Table 3)

\begin{tabular}{|c|c|c|}
\hline Study & Benign \% & Malignant\% \\
\hline${\text { Chalayini et } \mathrm{al}^{8}(2002)}$ ) & 70.44 & 29.56 \\
\hline Rafique $^{9}(2007)$ & 76.60 & 23.40 \\
\hline Aiffa Aiman et.al $^{7}(2010)$ & 77.20 & 22.80 \\
\hline Present study $\left.(2015)^{2}\right)$ & 81.13 & 18.87 \\
\hline
\end{tabular}

Table 3: Studies comparing benign \& malignant lesions

Out of 106 nephrectomies 82(77.66\%) were non neoplastic and 24(22.64\%) were neoplastic lesions. This observation is similar to study of Divyasree B.N. et al.10 where non-neoplastic were $72.41 \%$ \& neoplastic were $27.59 \%$ cases.

Among the nephrectomy cases 61 (57.55\%) were female patients \& 45 (42.45\%) were male patients. This finding is again similar to study of Divyasree B.N.et al ${ }^{10}$ who observed $51.5 \%$ of female $\& 48.5 \%$ of males. However it is at variable with E. Malik et al. ${ }^{11}$ reported $61 \%$ nephrectomies in males $\& 39 \%$ in females.

Majority of nephrectomies were in $5^{\text {th }}$ decade $(26.41 \%)$, followed by $4^{\text {th }}$ decade $(18.86 \%)$, this observation is varies with study of Mohammed. et. al.,12 who observed in $3^{\text {rd }}$ decade (30\%) followed by $4^{\text {th }}$ decade $(20 \%)$.

In the present study the most common clinical presentation was flank pain (80 patients), followed by fever (30 patients). This observation is more or less comparable with study conducted by Aiffa Aimann et al. ${ }^{7}$

In our study the most common lesion (64 cases) observed was chronic nonspecific pyelonephritis comprising $60.38 \%$ of total nephrectomies, which is followed by renal cell carcinoma $(11.32 \%)$ and tuberculous pyelonephritis $(11.32 \%)$. These findings are again correlating with the study of Aiffa Aimann et al ${ }^{7}$, Popat et al. ${ }^{13}$ 


\section{ORIGINAL ARTICLE}

In the present study, 2 cases (1.88\%) of xanthogranulomatous pyelonephritis were seen, both of them were associated with renal calculi \& found in female gender. This observation is matching with the studies of Siddappa et al,14 Ghalayani IF et al. ${ }^{8}$

Among 20 malignant neoplastic lesions of kidney in our study, the most common neoplasm encountered was renal cell carcinoma i.e. 12 cases (63.16\%), which is followed by Wilm's tumor i.e: 5 cases (26.36\%). This was similar to findings of Aiffa Aiman et al 7 \& Mohammed Rafique et al. ${ }^{9}$ Other rare neoplastic lesions were transitional cell carcinoma in adults \& clear cell sarcoma kidney \& congenital mesoblastic nephroma in childhood i.e: 1 case each. Among the renal cell carcinomas all the cases are seen in $5^{\text {th }}-7^{\text {th }}$ decades of life. This observation is similar to the observation by Mahesh Kumar et al. ${ }^{15}$

\begin{tabular}{|c|c|c|c|}
\hline & $\begin{array}{c}\text { Mahesh kumar et } \\
\text { al15 (7cases) }\end{array}$ & $\begin{array}{c}\text { Aiffa aimann et al7 } \\
\text { (25cases) }\end{array}$ & $\begin{array}{c}\text { Present } \\
\text { study(12cases) }\end{array}$ \\
\hline Clear cell type & $57.19 \%(4)$ & $80 \%(20)$ & $58.3 \%(7)$ \\
\hline Papillary type & $14.2 \%(1)$ & $12 \%(3)$ & $33.33 \%(4)$ \\
\hline Granular type & $14.2 \%(1)$ & $8 \%(2)$ & $8.3 \%(1)$ \\
\hline Sarcomatoid type & $14.2 \%(1)$ & 0 & 0 \\
\hline \multicolumn{2}{|c|}{ Table 4: Histological types of renal cell carcinoma in different studies }
\end{tabular}

In our study histological types of renal cell carcinomas were 7 (58.3\%) cases of clear cell type, 4 cases $(33.33 \%)$ were papillary variants \& 1 case $(8.3 \%)$ was chemophobe variant. This observation is similar to the observation noted by Mahesh Kumar et al ${ }^{15}$ \& Aiffa Aimann et al. ${ }^{7}$ (table 4)

Fuhrman nuclear grading in all the cases of renal cell carcinomas shows grade 2 to 3 nuclear feature. This observation again was similar to the study of Aiffa Aimann et al, 7 \& Popat et al.13

The present study included 5 cases of Wilm's tumor in the age group of 2 to 6 years which is correlating with the study of Argani P. et al.16 Microscopically 3 cases had triphasic (Blastemal, epithelial \& mesenchymal) lineage, and 2 cases had biphasic lineage.

In our study we observed one case of congenital mesoblastic nephroma, operated in a 11 days old infant, with history of maternal hydramnios, premature birth, abdominal mass. This observation is similar to the study of Daskas N et al. ${ }^{17}$

Other rare renal neoplasms we came across were; a case of clear cell sarcoma of kidney in a 12 year old female child was similar to observation of Aiffa Aimann et al ${ }^{7}$ \& Popat et al; ${ }^{13}$ comprising approximately $14 \%$ of pediatric renal tumors( 7 cases).This observation slightly differs from the study of Bo.Xie et. Al, ${ }^{18}$ who observed 4\% clear cell sarcoma kidney among childhood renal tumor. \& Argani P. et al. ${ }^{16}$ who's study has a peak incidence during 3-5 years, with a male: female ratio of 2:1

Other rare renal neoplasms we came across was 1 case of transitional cell carcinoma of renal pelvis in a 72 years old male patient comprising of $5 \%$ of renal neoplasms.

CONCLUSION: The present study provides a fair insight into the morphological patterns of lesions in nephrectomy specimens in our institution. There is a vast majority of non-functioning kidney due to inflammatory lesion is the indication for nephrectomy; whereas malignant neoplasms, (Most common being renal cell carcinoma) is the second common indication. A wide histopathological spectrum of lesions comprising both neoplastic and non-neoplastic lesions were encountered in nephrectomy specimens. Hence it is mandatory to study each specimen in detail along with clinical and radiological findings. 


\section{REFERENCES:}

1. Henriksen KJ, Meehan SM, Change A, et al. Non?neoplastic renal diseases are often unrecognized in adult tumor nephrectomy specimens: a review of 246 cases. Am J Surg Pathol 2007; 31: 1703?

2. Truong LD, Shen SS, Park MH, Krishnan B. diagnosing nonneoplastic lesions in nephrectomy specimens. Arch Pathol Lab Med 2009; 133: 189-200.

3. Flechner SM, Cow JG. Role of nephrectomy in the treatment of non-functioning or very poorly functioning unilateral tuberculous kidney. J Urol 1980; 123:822.

4. Kerr WK, Gale GL, Struthers NW. Prognosis in reconstructive surgery for urinary tuberculosis. Br J Urol 1970; 42:672.

5. Motzer RJ, Bancer NH, Nanus DM. Renal cell carcinoma. N Engl J Med 1996; 355: 865-75.

6. Bonsib SM. Cystic nephroma. Mixed epithelial and stromal tumor. In: Eble JN, Sauter G, Epstein JI, Sesterhenn IA, editors. World Health Organization classification of tumours. Pathology and genetics of tumors of the urinary system and male genital organs. Lyon: IARC Press; 2004. p. 76

7. Aiman A, Singh K, Yasir M. Histopathological spectrum of lesions in nephrectomy specimens: A five-year experience in a tertiary care hospital, Journal of the scientific Society, 2013, volume 40. issue 3,148-54

8. Ghalayini IF. Pathological spectrum of nephrectomies in a general hospital. Asian J Surg 2002; 25: 163-.

9. Rafique M. Nephrectomy: Indications, complications and mortality in 154 consecutive patients. J Pak Med Assoc 2007; 57: 308-117.

10. Divyashree B. N., Kusuma venkatesh, Madhusudhan H. R., Hanumantha Raju B. K,' 'Pathological spectrum of Non - Neoplastic Diseases in the Nephrectomy Specimens".Journal of Evidence based Medicine and Healthcare; Volume1, Issue 15, December 15, 2014; page; 1909-1920.

11. El Malik EM, Memon SR, Ibrahim AL, Al Gizawi A, Ghali AM. Nephrectomy in Adults: Asir Hospital Experience. Saudi J Kidney Dis Transpl 1997; 8: 423-7.

12. Muhammad Akmal, Khizar Ishtiaque Khan, Shahid Rana,Nephrectomy-an Overview,Pak J Surj,2012, 28(2); 102-105

13. Popat VC, Kumar MP, Udani D, Mundra MP, Vora DN, Porecha MM. A study on culprit factors ultimately demanding nephrectomy. Internet J Urol 2010; 7.

14. Siddappa S, Ramprasad K, Mythri Kuthagale Muddegowda.-Xanthogranulomatous pyelonephritis:A retrospective review of 16 cases.Korean J Urol,2011: 52:421-424.

15. Mahesh Kumar U., Yelikar BR*., Girija Patil, Mahesh H Karigoudar, Pankaj Pande and Patil SB.; Spectrum of Histopathological lesions in Nephrectomy specimens - A two year study in a tertiary care hospital; International Journal of Research in Pharmaceutical and Biomedical Sciences; Vol. 3 (4) Oct - Dec 2012;1787-90

16. Argani P, Pereman EJ, Breslow NE, Browning NG, Green DM, D’Angio GJ, et al. Clear cell sarcoma of the kidney: A review of 351 cases from the National Wilms Tumor Study Group Pathology centre. Am J Surg Pathol. 2000; 24: 4-18. [PubMed]

17. Daskas N, Argyropoulou M, Pavlou M, Andronikou Congenital mesoblastic nephroma associated with polyhydramnios and hypercalcemia. Pediatr Nephrol. 2002; 17: 187-9.[PubMed]

18. Bo Xie, Jiajun Ling. Clear cell sarcoma of the kidney - A case report. Chinese J Clin Onco. 2006; 2: $151-2$. 


\section{ORIGINAL ARTICLE}

\section{AUTHORS:}

1. Shaila

2. Nityananda B.S.

3. Tamil Arasi

PARTICULARS OF CONTRIBUTORS:

1. Assistant Professor, Department of Pathology, Kurnool Medical College, Kurnool.

2. Associate Professor, Department of Pathology, Kurnool Medical College, Kurnool.

FINANCIAL OR OTHER COMPETING INTERESTS: None
3. Professor \& HOD, Department of Pathology, Kurnool Medical College, Kurnool.

\section{NAME ADDRESS EMAIL ID OF THE CORRESPONDING AUTHOR:}

Dr. Tamil Arasi, Professor \& HOD, Department of Pathology, Kurnool Medical College, Kurnool.

E-mail: tamilarasi48@gmail.com

Date of Submission: 24/08/2015. Date of Peer Review: 25/08/2015. Date of Acceptance: 05/09/2015. Date of Publishing: 09/09/2015. 